\title{
SALURAN DISTRIBUSI PRODUK PANGAN JAJANAN ANAK SEKOLAH (PJAS) BERBASIS OLAHAN DAGING
}

\section{DISTRIBUTION CHANNEL OF MEAT BASED SNACK THAT IS CONSUMED BY SCHOOL STUDENTS}

\author{
R Hutami1a, ER Zain ${ }^{2}$, dan RF Theo ${ }^{1}$ \\ 1 Program Studi Teknologi Pangan dan Gizi, Fakultas Ilmu Pangan Halal, Universitas Djuanda Bogor \\ Jl. Tol Ciawi No. 1, Kotak Pos 35 Ciawi, Bogor 16720. \\ 1 Program Studi Teknologi Industri Pertanian, Fakultas Ilmu Pangan Halal, Universitas Djuanda Bogor \\ Jl. Tol Ciawi No. 1, Kotak Pos 35 Ciawi, Bogor 16720. \\ a Korespondensi: Rosy Hutami, E-mail: rosy.hutami@unida.ac.id \\ (Diterima: 02-02-2017; Ditelaah: 02-02-2017; Disetujui: 25-04-2017)
}

\begin{abstract}
Distribution channels play role in logistic activity of food product. In halal perspective, distribution channels have a strong relation with halalness of food product. The halalness of food product does not only depend on the origin of material but also guarantee of non-halal material free contamination during the product flow from point of product origin to point of product to be consumed. The aim of this research was to define the distribution channel of snack that is consumed by school students in Bogor city including meatball, sausage, and fried tapioca-filledwith-meat related to halal logistic perspective. The method of this research was by interview using questionnaire. Sampling method was by purposive sampling. Based on the result, the distribution channels in meatballs marketing, sausage marketing, and fried tapioca-filled-withmeat marketing were zero-level channel, three-level channel, and four-level channels, respectively. A longer distribution channel makes a greater number of logistic activities and it has a bigger potency of contamination of non-halal material to the halal product.
\end{abstract}

Keywords: fried tapioca-filled-with-meat, halal, level, logistic, marketing, meatball, sausage.

\begin{abstract}
ABSTRAK
Saluran distribusi berperan dalam aktivitas logistik dari suatu produk pangan. Dalam tinjauan halal, aktivitas logistik erat kaitannya dengan status kehalalan pangan. Kehalalan pangan tidak hanya bergantung pada bahan baku yang digunakan, tetapi juga jaminan bebas kontaminasi dari bahan yang diharamkan sepanjang aliran produk dari titik asal produk hingga ke titik tempat dikonsumsinya produk. Penelitian ini bertujuan mengetahui saluran distribusi dari produk pangan jajanan anak sekolah berbasis olahan daging berupa bakso, sosis, dan cireng isi daging di wilayah Bogor yang ditinjau dari perspektif kehalalan logistik. Metode yang digunakan dalam penelitian ini adalah dengan wawancara menggunakan alat bantu kuesioner. Penentuan sampel dilakukan secara purposive sampling. Berdasarkan hasil penelitian, saluran distribusi yang digunakan pada pemasaran bakso, sosis, dan cireng isi daging berturut-turut adalah zero-level channel, three-level channel, dan four-level channel. Semakin panjang saluran distribusi, semakin banyak aktivitas logistik yang dilakukan, dan semakin besar potensi kontaminasi produk halal dengan bahan yang nonhalal.
\end{abstract}

Kata kunci: bakso, cireng isi daging, halal, level, logistik, pemasaran, sosis.

Hutami R, ER Zain, dan RF Theo. 2017. Saluran distribusi produk pangan jajanan anak sekolah (PJAS) berbasis olahan daging. Jurnal Pertanian 8(1): 58-65. 


\section{PENDAHULUAN}

Saluran distribusi atau saluran pemasaran merupakan kelompok-kelompok atau lembaga yang terkait satu sama lain yang berperan dalam aliran proses barang atau jasa dari produsen ke pembeli (Szopa dan Pekala 2012). Distribusi merupakan proses pemindahan produk akhir perusahaan dari tangan produsen hingga ke tangan konsumen. Saluran distribusiyang baik diperlukan oleh pelaku usaha agar produknya dapat sampai ke tangan konsumen secara efektif, yaitu pada jumlah, tempat, dan waktu yang tepat sesuai dengan kebutuhan konsumen (Baeti 2007). Fungsi dari saluran distribusi ialah untuk menghubungkan dan menugaskan lembagalembaga yang terkait dalam hal perpindahan fisik dari barang atau jasa; perpindahan hak kepemilikan aktual dari barang atau jasa diantara para pelaku distribusi; informasi mengenai pembeli potensial, kompetisi, dan permintaan; promosi; tagihan pembayaran, negosiasi; pemesanan; pengambilan risiko; pengapalan, transportasi, dan penyimpanan barang (Szopa dan Pekala 2012). Para perantara dalam saluran distribusi bertanggung jawab terhadap fungsi-fungsi logistik yang mencakup pembelian, penawaran, penyimpanan, seleksi bahan, dan transportasi (Szopa dan Pekala 2012). Sehingga dapat diartikan bahwa, saluran distribusi sangat berkaitan dengan logistik.

Logistik merupakan seluruh aktivitas yang menyokong pergerakan dan koordinasi dari permintaan dan penawaran pada waktu dan tempat yang tepat (Heskett 1964). Logistik dapat pula didefinisikan sebagai proses dari perencanaan, implementasi dan pengawasan aliran dan penyimpanan barang/jasa, dan informasi dari titik asal barang/jasa tersebut hingga titik tempat dikonsumsinya barang/jasa untuk memenuhi kebutuhan konsumen (Lambert et al. 1998). Tujuan dari logistik adalah untuk memastikan bahwa konsumen dapat menikmati, menggunakan, atau mengonsumsi produk pada waktu yang tepat, jumlah yang tepat, dan dalam kondisi yang baik. Manajemen logistik menghubungkan serangkaian aktivitas yang mencakup transportasi, penyimpanan dan penggudangan, manajemen inventaris, manajemen bahan, pengaturan produk, dan pelayanan konsumen.

Dalam perspektif halal, semua produk halal harus sesuai dengan ketentuan Syariah yang mengungkapkan bahwa produk bukan berasal dari bahan yang dilarang, tidak berbahaya dan sehat langsung dari asal sampai konsumsi akhir. Dengan demikian, dalam perspektif logistik halal, harus dipastikan bahwa produk selama aktivitas logistik apapun, seperti transportasi atau penyimpanan, harus berpegang pada prinsipprinsip Syariah (Ab Talib dan Hamid 2014). Hal ini sejalan dengan konsep manajemen rantai pasok halal (Tieman 2011) bahwa distribusi, penyimpanan, penanganan, dan pembelian dari produk harus mengikuti prinsip Syariah agar dapat dinyatakan sebagai produk Halal.

Penelitian mengenai saluran distribusi yang sudah dilakukan antara lain mengenai peranan saluran distribusi dalam pemasaran produk dan jasa (Lubis 2004); analisis efektivitas saluran distribusi produk minuman dalam kemasan (Baeti 2007); saluran distribusi peralatan pengolahan pangan pada suatu unit usaha (Hahury 2010); pentingnya saluran distribusi dan saluran pemasaran untuk ekonomi nasional (Segetlija et al. 2012); dan saluran distribusi dan aturannya dalam dunia usaha (Szopa dan Pekala 2012). Secara umum, kaitan antara saluran distribusi, halal logistic, dan managemen rantai pasok dibahas secara garis besar oleh Nor et al. (2010).

Kajian mengenai saluran distribusi pangan jajanan anak sekolah (PJAS) masih sangat terbatas, terutama bila dikaitkan dengan aspek kehalalan logistik. Kajian ini sangat penting, mengingat kehalalan PJAS tidak hanya bergantung pada bahan baku yang digunakan dalam produknya, tetapi juga dipengaruhi oleh semua aktivitas logistik yang bersentuhan dengan produk PJAS tersebut seperti transportasi, penyimpanan, dan penanganan produk. Aktivitas logistik ini dilakukan oleh saluran distribusi PJAS. Untuk itu, penelitian ini dibuat untuk mengetahui 
saluran distribusi dari produk pangan jajanan anak sekolah berbasis olahan daging berupa bakso, sosis, dan cireng isi daging di wilayah Bogor dan kaitannya dengan aspek kehalalan logistiknya.

\section{MATERI DAN METODE}

\section{Materi}

Penelitian ini dilaksanakan di dua belas sekolah dasar negeri (SDN) di wilayah kota Bogor. Kriteria pemilihan SDN dilakukan secara purposive sampling, yaitu berada di wilayah kota Bogor, lokasi dekat dengan pasar, dan kelengkapan jenis PJAS yang dijual. Penelitian ini dilaksanakan selama dua bulan dari bulan Mei sampai Juni 2016.

\section{Metode}

Penelusuran saluran distribusi produk dilakukan dengan metode survei dengan teknik wawancara. Alat yang digunakan berupa kuesioner. Prosedur penelitian dapat dilihat pada Gambar 1.

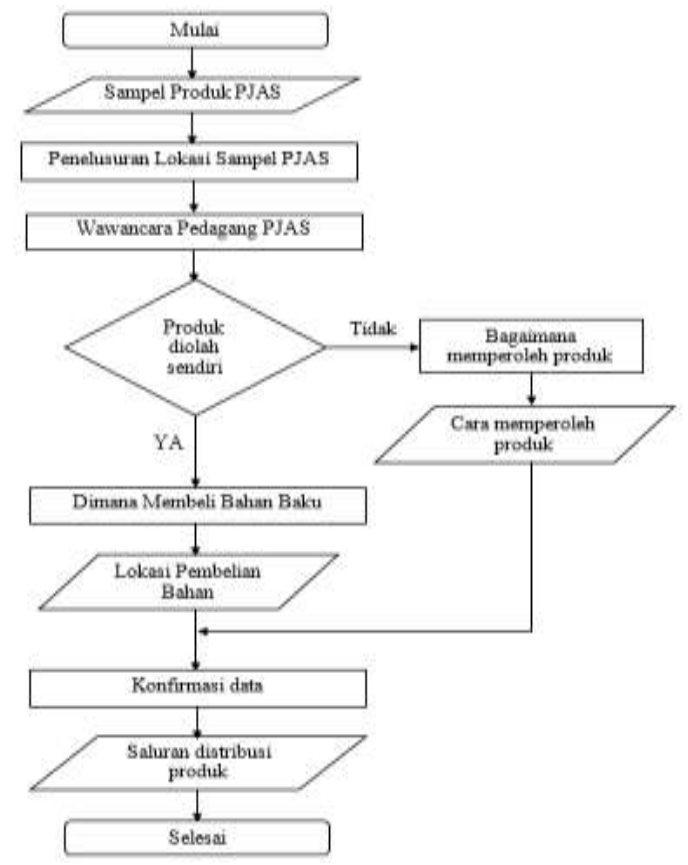

Gambar 1 Prosedur Penelitian

Jenis data yang digunakan dalam penelitian ini merupakan data primer. Data hasil wawancara responden dianalisis secara deskriptif untuk menggambarkan saluran distribusi produk PJAS di wilayah Kota Bogor.

\section{HASIL DAN PEMBAHASAN}

\section{Saluran Distribusi Produk PJAS}

Saluran distribusi digunakan perusahaan untuk mengefisiensikan biaya distribusi dalam menjalankan pemasaran secara langsung dan untuk memperluas pangsa pasar. Keputusan saluran distribusi merupakan salah satu keputusan penting yang harus dilakukan oleh setiap manajemen. Saluran-saluran yang dipilih perusahaan atau pelaku usaha mempengaruhi langsung setiap keputusan pemasarannya. Saluran distribusi ini menyangkut cara penyampaian produk ke tangan konsumen. Pimpinan atau pelaku usaha harus mampu menganalisis keadaan pasar sehingga dapat menjangkau konsumen yang ada dengan harga yang menarik dan memilih saluran distribusi yang digunakan untuk menyalurkan produk (Hahury 2010). Kegiatan saluran distribusi produk PJAS dilakukan untuk mengetahui aliran penyaluran produk dari produsen hingga sampai ke tangan konsumen. Produk yang digunakan sebagai sampel PJAS dalam penelitian ini adalah bakso, sosis, dan cireng isi daging.

\section{Saluran Distribusi Produk Bakso}

Bahan baku produk bakso adalah daging sapi. Daging sapi diperoleh dari pasar di wilayah kota Bogor. Pasar yang dikunjungi oleh pedagang bakso untuk membeli daging sapi adalah Pasar Bogor dan Pasar Anyar. Alasan kedua pasar tersebut dipilih sebagai tempat membeli daging sapi, yaitu dekat dengan rumah produsen yang sekaligus sebagai lokasi pengolahan produk, harga yang bersaing, dan adanya jasa penggilingan daging. Daging sapi yang telah dibeli selanjutnya diolah oleh pedagang bakso. Sebelum diolah, daging sapi digiling terlebih dahulu. Pedagang bakso biasanya menggiling daging di pasar yang digunakan sebagai temapt membeli daging. Umumnya, pedagang bakso menggunakan jasa penggilingan daging dibandingkan menggilingnya sendiri. Delapan dari delapan pedagang bakso yang digunakan sebagai responden, semuanya menggunakan jasa penggilingan daging yang ada di pasar tempat membeli daging. Alasan pedagang lebih 
memilih jasa penggilingan daging dibandingkan dengan menggiling sendiri, yaitu tidak memiliki mesin penggilingan, lebih prkatis, hemat waktu, dan tenaga (jika menggiling sendiri membutuhkan waktu dan tenaga lebih untuk mengolah bakso).

Penggunaan mesin penggiling menjadi titik kritis kehalalan produk bakso. Mesin penggiling yang digunakan untuk menggiling daging sapi apabila tidak dipisahkan dan digunakan bersama untuk menggiling daging babi dapat menjadi kontaminasi kehalalan sehingga produk menjadi tidak halal. Hal ini yang tidak dapat diawasi dan dikendalikan oleh pedagang bakso dalam menjamin kehalalan produknya. Daging halal yang bersentuhan dengan alat yang telah terkontaminasi babi dapat tercemar kandungan babi. Alat yang telah terkontaminasi babi tentunya disebabkan oleh cemaran babi yang ada pada produk yang dipalsukan. Alat penggilingan yang telah tercemar kandungan babi akan menimbulkan cemaran babi pula pada setiap produk penggilingan yang ada setelahnya (Setiawan 2013). Penelitian mengenai identifikasi mesin penggiling sebagai kontaminasi kehalalan telah dilakukan oleh Setiawan (2013). Penggilingan bakso yang terdapat di Pasar Bogor dan Pasar Anyar terbukti tidak mengandung cemaran babi berdasarkan pengujian dengan menggunakan porcine detection kit (Setiawan 2013). Hal tersebut diperkuat dengan hasil penelitian yang menunjukkan hasil negatif terhadap protein babi pada semua produk bakso dengan menggunakan porcine detection kit.

Pedagang bakso bertindak sebagai produsen dalam saluran distribusi produk bakso. Pedagang bakso mengolah sendiri daging sapi yang telah dibeli dan digiling di pasar yang sama. Apabila bakso tidak terjual habis pada hari itu, maka bakso akan disimpan dalam alat pendingin dan dijual keesokan harinya atau dikonsumsi sendiri apabila jumlah bakso yang tidak terjual hanya sedikit. Jika harga bahan baku daging sapi naik, pedagang bakso mengatasi permasalahan tersebut dengan memperkecil ukuran bakso dengan harga jual yang sama. Pedagang bakso menjual produknya secara langsung ke konsumen tanpa melalui perantara dengan cara menetap di lokasi penjualan, yaitu sekolah dasar negeri (SDN). Konsumen dari bakso ini adalah para siswa SDN, orang tua murid, dan atau masyarakat disekitar lokasi berjualan pedagang bakso. Konsumen memperoleh produk bakso dengan cara membeli produk tersebut dari pedagangpedagang bakso yang berada di SDN.

Saluran distribusi yang digunakan oleh pedagang bakso (produsen) dalam menyalurkan produknya ke konsumen adalah saluran distribusi zero-level channel. Saluran ditribusi zero-level channel atau saluran distribusi langsung adalah saluran yang ditempuh oleh produsen dimana pedagang bakso sebagai produsen bakso menyalurkan secara langsung produknya kepada konsumen tanpa melalui perantara (Kotler 2005). Pemilihan saluran distribusi tersebut dikarenakan beberapa pertimbangan, diantaranya skala produksinya masih rendah sehingga produsen lebih memilih untuk menjual secara langsung kepada konsumen untuk memaksimalkan laba yang didapat dan produk bakso termasuk kategori produk perishable, yaitu produk yang mudah rusak bila disimpan tanpa perlakuan penanganan (pengawetan) sehingga apabila tidak langsung disalurkan maka produk akan rusak sebelum sampai di tangan konsumen (Muchtadi dan Sugiyono 2013). Skema saluran yang digunakan oleh pedagang bakso dapat dilihat pada Gambar 2.

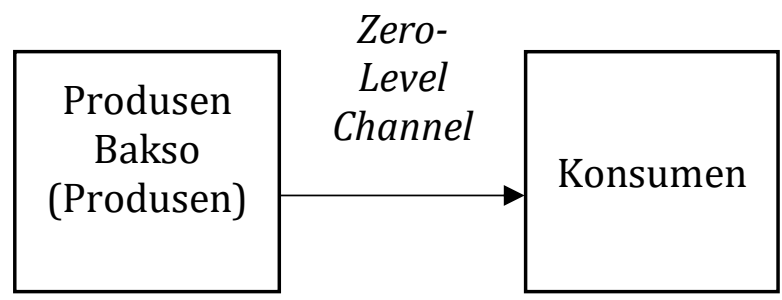

Gambar 2 Struktur saluran distribusi zerolevel channel produk bakso

Pelaku aktivitas kritis kehalalan logistik pada produk bakso PJAS terletak pada produsen bakso yang merangkap pedang bakso. Produsen bakso bertanggung jawab dalam penggunaan bahan baku yang halal dan penggunaan mesin penggiling daging yang terbebas dari kontaminasi bahan yang diharamkan. 


\section{Saluran Distribusi Produk Sosis}

Asumsi awal dalam penelitian ini adalah sosis yang dijual oleh pedagang sosis adalah sosis yang diolah sendiri yang bahan baku dagingnya dibeli di pasar atau sosi curah (sosis tanpa kemasan) yang dibeli di pasar. Namun, sosis yang digunakan oleh pedagang sosis berasal dari industri olahan daging bukan menggunakan sosis curah yang bisa diperoleh di pasar atau sosis yang diolah sendiri oleh pedagang. Delapan dari delapan pedagang yang dijadikan responden menyatakan bahwa seluruh pedagang menggunakan sosis dari industri olahan daging. Alasan pedagang lebih memilih menggunakan sosis dari industri olahan daging daripada menggunakan sosis curah dan sosis yang diolah sendiri, yaitu terbatasnya alat, lebih praktis, hemat waktu, tenaga, dan biaya.

Titik kritis kehalalan produk sosis terletak pada industri olahan daging sebagai produsen sosis yang digunakan oleh pedagang sosis. Hasil penelusuran saluran distribusi menunjukkan bahwa produk sosis yang digunakan adalah sosis kemasan yang telah memiliki logo halal MUI. Namun, peneliti memeriksa merk produk sosis tersebut dengan cara memeriksa no. daftar halalnya di daftar belanja LPPOM MUI dengan menggunakan aplikasi Halal MUI untuk memastikan status kehalalan produk sosis tersebut. Hasil pemeriksaan menunjukkan bahwa merk sosis yang digunakan oleh pedagang sosis terdaftar dalam daftar produk halal LPPOM MUI dengan status halal yang masih berlaku dan belum kadaluarsa.

Pedagang sosis memperoleh produk sosis melalui agen. Alasan menggunakan agen dalam memperoleh produk sosis, yaitu lebih praktis (tidak perlu pergi untuk memperoleh produk karena produk diantarkan ke pedagang), harga relatif lebih murah, hemat biaya, waktu, dan tenaga. Agen adalah perantara yang melakukan jual beli dimana tidak memiliki hak atas barang tersebut dan tidak menanggung risiko yang menyangkut atas pemilikan barang-barang tersebut (Baeti 2007). Agen bertindak sebagai perantara yang menyalurkan produk sosis dari produsen ke pedagang sosis. Pedagang sosis pada rantai distribusi ini bertindak sebagai pengecer. Pengecer adalah seorang pedagang yang melakukan penjualan secara langsung kepada konsumen akhir (Baeti 2007). Pedagang sosis menjual produk sosis secara satuan ke konsumen dengan cara mendatangi tempat dimana konsumen berada. Pada saat penyaluran dari pedagang sosis ke konsumen, hal ini dapat menjadi titik kritis kehalalan. Produk sosis yang digunakan oleh pedagang sosis sudah memiliki sertifikat halal, tetapi dalam penyajiannya ke konsumen bisa terjadi kontaminasi terhadap kehalalan produk. Apabila pedagang sosis menggunakan bahanbahan non halal dalam menyajikan produknya ke konsumen maka produk yang halal menjadi tidak halal.

Saluran distribusi yang digunakan oleh produsen sosis dalam menyalurkan produknya ke tangan konsumen adalah saluran distribusi three-level channel. Pada saluran distribusi three-level channel, produsen sosis menyalurkan produknya ke konsumen melalui dua perantara, yaitu agen dan pengecer (Kotler 2005). Skema saluran yang digunakan oleh produsen sosis dapat dilihat pada Gambar 3.

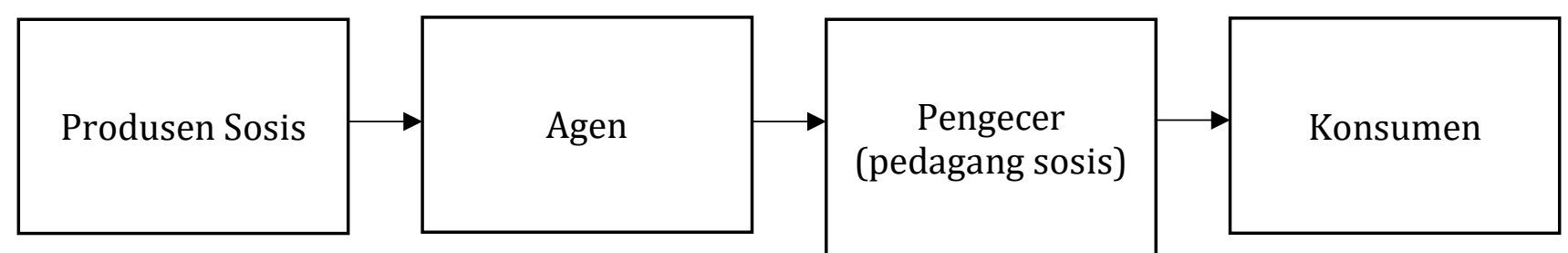

Gambar 1 Struktur saluran distribusi three-level channel produk sosis

Pelaku aktivitas kritis kehalalan logistik pada produk sosis PJAS terletak pada produsen sosis, agen, dan pengecer. Produsen sosis bertanggung jawab dalam penggunaan bahan baku yang halal, penyimpanan, dan transportasi produk yang terbebas dari kontaminasi bahan yang diharamkan. Agen betanggung jawab dalam penyimpanan dan 
transportasi produk yang terbebas dari kontaminasi bahan yang diharamkan. Pengecer bertanggung jawab dalam penyiapan dan penyajian produk sosis yang terbebas dari kontaminasi bahan yang diharamkan.

\section{Saluran Distribusi Produk Cireng Isi Daging}

Cireng isi daging adalah produk berbahan dasar sagu dengan penambahan daging sebagai bagian variatif dari produk cireng. Cireng isi daging dalam penelitian ini adalah cireng dengan kornet daging sapi sebagai bahan pengisi cireng. Kornet daging sapi yang digunakan oleh produsen cireng isi daging dapat berasal dari berbagai sumber diantaranya kornet kalengan, daging halus curah dalam kemasan, atau daging giling curah. Asumsi awal dalam penelitian ini adalah kornet yang digunakan sebagai bahan pengisi diolah sendiri dengan menggunakan daging sapi halus curah atau daging giling curah yang dapat dibeli di pasar. Namun, delapan dari delapan produsen cireng isi daging yang dijadikan responden menyatakan lebih memilih menggunakan kornet kalengan daripada menggunakan daging halus curah atau daging giling curah. Alasan produsen lebih memilih menggunakan koret kalengan sebagai bahan pengisi cireng, yaitu rasanya lebih enak, lebih mudah disimpan, hemat waktu dan tenaga.

Titik kritis kehalalan produk cireng isi daging terletak pada produsen kornet daging sapi yang digunakan oleh pedagang kornet. Hasil penelusuran saluran distribusi menunjukkan bahwa produk kornet yang digunakan adalah kornet daging sapi kalengan yang telah memiliki logo halal MUI. Namun, peneliti memeriksa merk kornet kalengan tersebut dengan cara memeriksa nomor daftar halalnya di daftar belanja LPPOM MUI dengan menggunakan aplikasi Halal MUI untuk memastikan status kehalalan produk sosis tersebut. Hasil pemeriksaan menunjukkan bahwa merk kornet kalengan yang digunakan oleh pedagang sosis terdaftar dalam daftar produk halal LPPOM MUI dengan status halal yang masih berlaku dan belum kadaluarsa.
Produsen cireng isi daging memperoleh kornet melalui agen. Agen adalah perantara yang menyalurkan produk kornet dari produsen kornet ke produsen cireng isi daging. Alasan menggunakan agen dalam memperoleh kornet, yaitu lebih praktis (tidak perlu pergi untuk memperoleh produk karena produk diantarkan ke pedagang), hemat waktu, dan hemat tenaga. Kornet selanjutnya digunakan oleh produsen cireng isi daging dalam pengolahan produk sebagai bahan pengisi. Produsen cireng isi daging pada rantai distribusi ini bertindak sebagai pedagang besar. Pedagang besar adalah sebuah unit usaha yang membeli barang dagangan dan menjualnya kembali kepada pengecer serta pedagang lain atau kepada lembaga industri serta pemakai komersial (Baeti 2007). Produsen cireng isi daging menyalurkan produknya ke tangan konsumen melalui pengecer. Pengecer adalah seorang pedagang yang melakukan penjualan secara langsung kepada konsumen akhir. Pengecer menjual produk ke konsumen dengan cara menetap di lokasi dimana konsumen berada, yaitu sekolah dasar negeri (SDN).

Pengolahan produk cireng isi daging oleh produsen dan penyajian produk cireng isi daging oleh pengecer ke konsumen dapat menjadi titik kritis kehalalan produk cireng isi daging selain pada kornet yang digunakan sebagai bahan pengisi. Pada saat pengolahan produk cireng isi daging, ada kemungkinan produsen menggunakan bahan non halal sebagai campuran bahan sehingga produk menjadi tidak halal. Pada saat penyajian produk cireng isi, daging ada kemungkinan pengecer menambahkan bahan non halal dalam menyajikan produk ke konsumen. Namun, hal tersebut tidak terjadi. Hal ini dibuktikan dengan hasil uji pada produk cireng isi daging yang menunjukkan hasil negatif. Berdasarkan uraian diatas, saluran distribusi yang digunakan pada produk cireng isi daging adalah saluran distribusi four-level channel. Pada saluran distribusi ini, produk cireng isi daging disalurkan ke tangan konsumen melalui tiga perantara, yaitu agen, pedagang besar (grosir), dan pengecer (Kotler 2005 dalam Baeti 2007). Skema saluran 
distribusi untuk produk cireng isi daging dapat dilihat pada Gambar 4.

Pelaku aktivitas kritis kehalalan logistik pada produk cireng isi daging PJAS terletak pada produsen kornet, agen, produsen cireng isi daging dan pengecer. Produsen kornet bertanggung jawab dalam penggunaan bahan baku yang halal, penyimpanan, dan transportasi produk yang terbebas dari kontaminasi bahan yang diharamkan. Agen betanggung jawab dalam penyimpanan dan transportasi produk yang terbebas dari kontaminasi bahan yang diharamkan. Produsen cireng isi daging bertanggung jawab dalam pengolahan produk yang terbebas dari kontaminasi bahan yang diharamkan. Pengecer bertanggung jawab dalam penyiapan dan penyajian produk cireng isi daging yang terbebas dari kontaminasi bahan yang diharamkan.

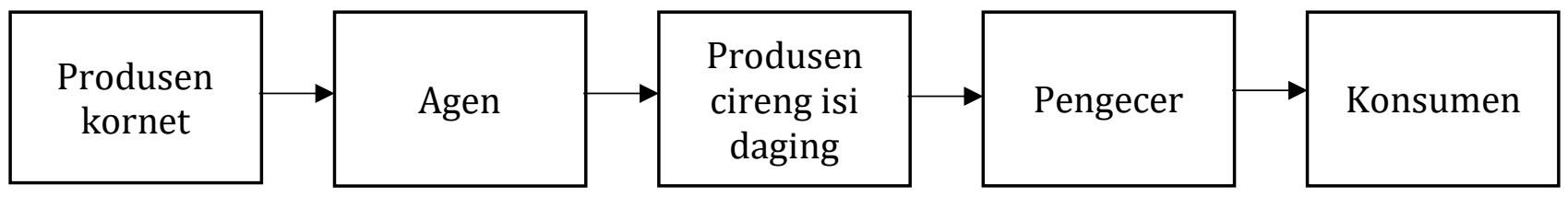

Gambar 4 Struktur saluran distribusi four-level channel produk cireng isi daging

\section{KESIMPULAN DAN IMPLIKASI}

Saluran distribusi pada produk bakso adalah saluran distribusi zero-level channel yang terdiri dari produsen dan konsumen. Saluran distribusi pada produk sosis adalah saluran distribusi three-level channel yang terdiri dari produsen, agen, pengecer, dan konsumen. Saluran distribusi pada produk cireng isi daging adalah saluran distribusi four-level channel yang terdiri dari produsen, agen, pedagang besar, pengecer, dan konsumen. Saluran distribusi mempengaruhi kehalalan produk pangan jika ditinjau dari perspektif halal logistic. Semakin panjang saluran distribusi, maka banyak semakin banyak aktivitas logistik yang terbentuk dan semakin besar peluang kontaminasi produk dengan bahan yang diharamkan.

\section{UCAPAN TERIMA KASIH}

Penelitian ini merupakan bagian dari program Hibah Penelitian Dosen Pemula Kemenristek DIKTI tahun pendanaan 2016. Terima kasih kepada Direktorat Jenderal Penguatan Riset dan Pengembangan Kementerian Riset, Teknologi, dan Pendidikan Tinggi atas pembiayaan penelitian ini sesuai dengan Surat Perjanjian Penugasan Pelaksanaan Hibah Penelitian Nomor : 105/SP2H/PPM/DRPM/II/2016, tanggal 17 Februari 2016.

\section{DAFTAR PUSTAKA}

Ab Talib MS dan ABA Hamid. 2014. Halal logistics in Malaysia: a SWOT analysis. Journal of Islamic Marketing, 5(3), 322-343.

Baeti EN. 2007. Analisis efektivitas saluran distribusi fruit tea di wilayah Bogor (studi kasus pada kantor penjualan Bogor PT. Sinar Sosro). Skripsi. Institut Pertanian Bogor, Bogor.

Hahury HD. 2010. Penentuan saluran distribusi oven pada UD. Swan Jaya di Kota Ambon. Jurnal Ekonomi. Vol. 4 (2): 10-21.

Heskett JL. 1964. Business Logistics: Management of Physical Supply and Distribution: Ronald Press Co.

Kotler P. 2005. Manajemen Pemasaran Jilid 2. Edisi ke-11. Indeks, Jakarta.

Lambert DM, JR Stock, and LM Ellram. 1998. Fundamentals of Logistics Management. McGraw-Hill, Singapore.

Lubis AN. 2004. Peranan saluran distribusi dalam pemasaran produk dan jasa. Diunduh pada 28 Maret 2017 dari http://repository.usu.ac.id/bitstream/123 456789/1234/1/manajemenarlina\%20lbs4.pdf

Muchtadi TR dan Sugiyono. 2013. Prinsip proses dan teknologi pangan. Alfabeta, Bandung.

Nor MRM, K Latif, MN Ismail, and MN Nor. 2016. Critical Success Factors of Halal Supply Chain Management from the Perspective of Malaysian Halal Food Manufacturers. Arabian Journal of Business 
and Management Review (Nigerian Chapter) Vol. 4 (1) : 1-23.

Segetlija Z, J Mesarić, and D Dujak. 2012. Importance of Distribution Channels Marketing Channels - for National Economy. Croatia : University of J.J.Strossmayer. Diunduh pada 28 Maret 2017 dari https://bib.irb.hr/datoteka/529824.Segetl ija_Dujak_Mesaric.pdf..

Setiawan LE. 2013. Validasi porcine detection kit pada analisis cemaran babi dalam produk daging sapi. Skripsi. Institut Pertanian Bogor, Bogor.
Szopa P and W Pekala. 2012. Distribution Channels and Their Roles in the Enterprise. Polish Journal Of Management Studies vol 6 : 143-150. Diunduh pada 28 Maret 2017 http://www_pjms_zim_pcz_plpdfpjms6dis tribution20channels20and20their20roles 20in20the20enterprise.pdf.

Tieman M. 2011. The application of halal in supply chain management: in-depth interviews. Journal of Islamic Marketing, 2(2), 186-195. 